\title{
ETHNOBOTANICAL TOURISM POTENTIAL IN BALI BOTANICAL GARDEN
}

\section{G. Wawan Setiadi dan Renata Lusilaora Siringoringo \\ Bali Botanical Garden - Indonesian Institute of Sciences (LIPI)}

\begin{abstract}
Natural resources of Indonesia provide plenty of opportunities for development and growth of tourism activities. Nature tourism was then developed and the development patterns shifted into those of special interest tourism and ecological tourism. Bali Botanical Garden is located in Bedugul tourist area; however, it has not become a major tourist destination for both domestic and foreign visitors. Bali Botanical Garden mainly functions as a place for plant conservation, research, environmental education, and tourism. Various tourism activities can be conducted in this garden, including ethnobotanical study tours. This can be seen from the existing thematic collections, including Panca Yadnya Garden, Usada Medicinal Garden, and Balinese Traditional Houses with an ethnobotanical museum. This study aims to analyze the potential of ethnobotanical tourism in Bali Botanical Garden. This study used a descriptive-qualitative method and the data consisted of primary and secondary data. Promotional activities must be intensified in order that the ethnobotanical tourism potential can be developed further and has positive benefits for science, the tourism industry and the welfare of the communities.
\end{abstract}

Keywords : Ecotourism, Bali Botanical Garden, Ecotourism Potential, Development of Ecotourism

\begin{abstract}
Abstrak
Sumber daya alam Indonesia memberikan banyak peluang bagi pengembangan dan pertumbuhan kegiatan pariwisata. Wisata alam kemudian dikembangkan dan pola pengembangan bergeser menjadi orang-orang dari wisata minat khusus dan wisata ekologi. Kebun Raya Bali terletak di kawasan wisata Bedugul, namun, hal itu belum menjadi tujuan wisata utama bagi pengunjung domestik dan asing. Kebun Raya Bali memiliki fungsi yang terutama yaitu berfungsi sebagai tempat konservasi tanaman, penelitian, pendidikan lingkungan, dan
\end{abstract}


pariwisata. Berbagai kegiatan pariwisata dapat dilakukan di Kebun Raya Bali, termasuk etnobotani tur studi. Hal ini dapat dilihat dari koleksi tematik yang ada, termasuk adanya Taman Panca Yadnya, Taman Obat Usada, dan rumah/penginapan yang di desain dengan konsep tradisional Bali dengan dilengkapi museum etnobotani. Penelitian ini bertujuan untuk menganalisis potensi pariwisata etnobotani di Kebun Raya Bali. Penelitian ini menggunakan metode deskriptif-kualitatif dan data terdiri dari data primer dan sekunder. Kegiatan promosi harus diintensifkan agar potensi wisata etnobotani dapat dikembangkan lebih lanjut dan memiliki manfaat positif bagi ilmu pengetahuan, industri pariwisata dan kesejahteraan masyarakat.

Kata kunci: ekowisata, Kebun Raya Bali, ekowisata potensi, pengembangan ekowisata

\section{Introduction}

The charm of the nature and the Hindu culture which maintains the balance of the relationship between man and nature in life are treasures owned by the Balinese people and magnets that attract tourists to come to Bali. The island of Bali has become an icon of Indonesian tourism that is known worldwide. Tourism is a non-oil and gas industry that serves as a primary sector in generating foreign exchange in several countries in the world such as the United States, Australia, Thailand, Singapore, Malaysia, and Indonesia. Tourism is one of the industries that has the power to rapidly increase the economic growth, create job opportunities, increase people's income and living standards, and stimulate other productivity sectors, such as handicraft and souvenir industries, accommodation and transportation.

Three potentials for tourism that exist in Bali such as the natural beauty, the unique culture, and the friendly people have made this island one of the international tourist destinations that enjoys worldwide fame. The tourism sector has been the engine for economic growth and development in Bali since the 1970s. Hence, tourism is very closely related to and inseparable from the life of the people and the development of the island.

Nature tourism, or commonly called ecotourism, has become one aspect of tourism activities in Bali. According to Damanik and Weber (2006), Indonesia is blessed with a considerable number of potential ecotourism areas. Those areas are spread out both on land (within conservation areas) and at sea (taking the form of national marine parks). Based on the existing various potentials, development needs to be done in order to increase the diversity of tourist attractions on offer. 
Bedugul tourist area is renowned for the beauty of Lake Beratan and Ulun Danu Temple. In that area stands Kebun Raya Bali (Bali Botanical Garden), a botanical garden that serves as a plant conservation area with beautiful scenery. A wide range of plant species are collected and arranged into a garden, which has become one of the natural tourist destinations both for domestic and foreign travelers. In addition to plants, Bali Botanical Garden also keeps a wealth of information and data on ethnobotany.

Ethnobotany is the scientific study of the direct relationships that exist between peoples and plants, in the context of how peoples have traditionally been making use of plants, for example, how plants have been processed into herbal drinks that are beneficial to health. Ethnobotany studies traditional use of plants by primitive tribes, and the results of the study were presented at a meeting of an archaeological association in 1895 by Harsberger. Ethnobotany literally means science that studies the botany of the local community. It is a study that researches the relationship that takes place between a traditional community and its vegetal environment. Today, ethnobotany is described as a reciprocal relationship between man and plants. This branch of study aims to explain the culture of ethnic groups in making use of plants as food, clothing, medicines, dyes and others.

\section{Method}

This study was conducted in March 2016 in Bali Botanical Garden, Candikuning Village, Baturiti Sub-Disctrict, Tabanan Regency, Bali. In this study, the data of tourism potentials that were used include: Biological potential (flora); Ethnobotanical potential; Physical potential (accessibility, infrastructures and the supporting facilities and infrastructures); Human resources.

This study was conducted using the descriptive-qualitative method. This stage includes the collection of secondary data and primary data, which involves the preparation of tools and materials to be used for research activities, and field orientation. A series of steps taken in the data collection stage includes: (1) conducting a literature research; (2) collection of data and field observation. The analyses used in this study consisted of the existing analysis in Bali Botanical Garden and SWOT analysis.

\section{Findings and Discussion}

\section{A. General Condition of Bali Botanical Garden}

Bali Botanical Garden is located in the village of Candikuning, Baturiti, Tabanan Regency, Bali, on an area of 157.5 ha. In early 1958, the authorities in Bali made a proposal to the Institute of Nature Study, Ministry of Agriculture, now Biological Research and Development Center within the Indonesian Institute of Sciences (LIPI), to consider the establishment of a botanical garden in Bali. Based on the proposal, the Director of the Institute 
of Nature Study Prof. Ir. Kusnoto Setyodiwirjo accompanied by the Head of Bogor Botanical Garden, Head of Marine Research, Director of the Academy of Agriculture, and several students of the Academy of Agriculture conducted a review visit to Bali. The result of the visit, taking into consideration the location, the potential and the objectives, was that the site would be developed into: (1) a place to collect the Gymnospermae plant species found throughout the world, such as pandak pine (dacrycarpus imbricatus (Blume) de Laub); (2) a place to collect plant species from all over Bali and Nusa Tenggara that grow in wet highlands; (3) a place for recreation and a center for scientific and cultural studies.

The plan was realized with the approval of the use of a 50-hectare reforestation land located east of Bukit Tapak (Tapak Hill). This botanical garden was inaugurated on 15 July 1959 and by I Made Taman was named Kebun Raya Eka Karya (Eka Karya Botanical Garden). As the garden was developed, on 30 April 1976 the expansion of Kebun Raya Eka Karya was officially approved by the Chairman of LIPI, and the garden now occupied an area of 129.20 ha. After the re-measurement in 1993, the area is now 154.50 hectares, constituting a reforestation area of Bukit Tapak, sitting at an altitude of 1,250-1,450 meters above sea level, under a permit to use from the Department of Forestry. Today, Bali Botanical Garden has the main tasks of carrying out the inventory, exploration, collection, maintenance, re-introduction, development, data collection, documentation, science services, dissemination of science in the field of conservation, and introduction of plants that grow on dry highlands that have an economic value to be collected in a botanical garden (Decision of Chairman of LIPI No. 1019/M/2002). To carry out the above tasks, the Technical Implementation Unit of Plant Conservation Center at Bali Botanical Garden, LIPI has the following functions:

1) Conduct an inventory of various tropical plant species that grow in dry highlands.

2) Assist in exploration of tropical plant species that grow in dry highlands.

3) Conduct conservation of tropical plants that grow in dry highlands, i.e. those that have a scientific value and economic potential, in order to preserve the vegetal resources in Indonesia.

4) Conduct researches on plants, especially in the field of biosystematics, propagation, re-introduction, ecology and conservation.

5) Provide scientific services in the field of garden landscape architecture, ornamental plant varieties (floriculture), introduction to the usefulness of flora that grow in dry highlands, and services to raise public appreciation towards the tropical environment.

6) Establish cooperation in the field of botanical gardens both nationwide and internationally. 


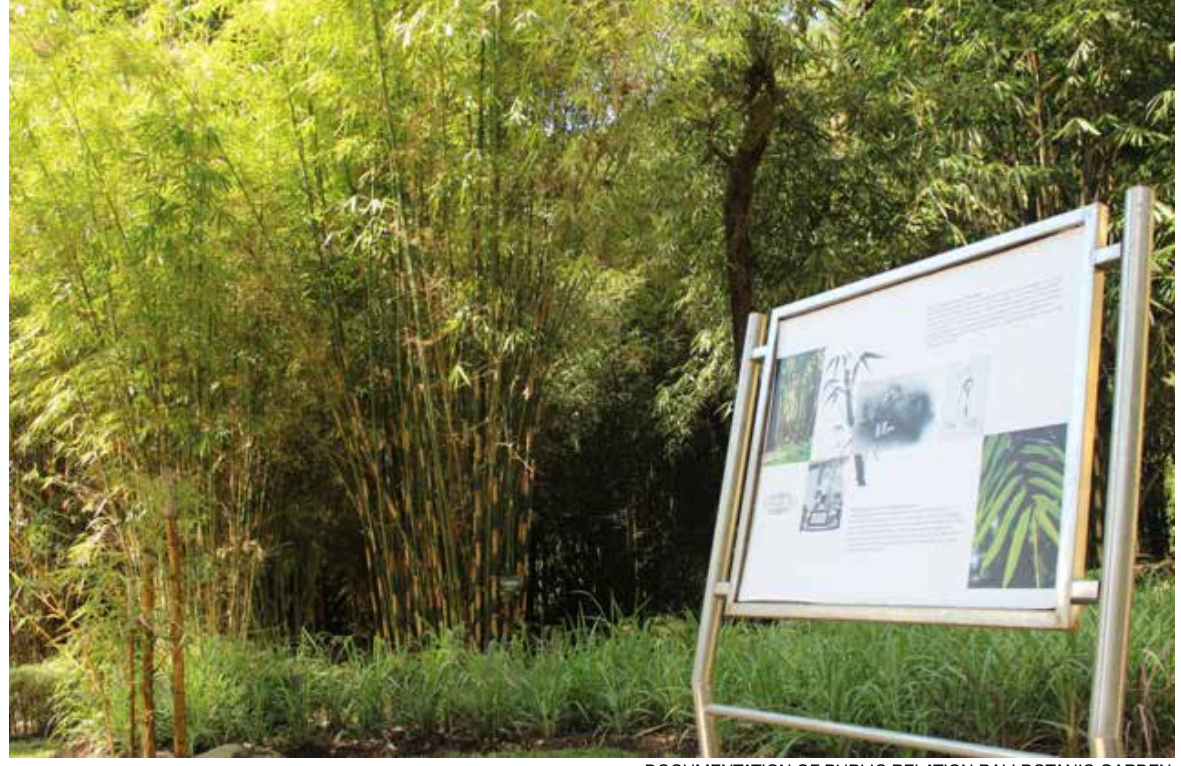

Figure 1. Bamboo Garden.

DOCUMENTATION OF PUBLIC RELATION BALI BOTANIC GARDEN

7) Evaluate the results of the inventory of flora that grow in dry highlands and prepare reports.

8) Perform administrative work.

\section{B. Plant Collections}

Plant collections in Bali Botanical Garden are divided into two groups: general collections and thematic collections. General collections are grouped based on the kinship (family) of plants, and planted on specific plots. Thematic collections are the collections of plants grown specifically with a certain theme and grouped on the basis of their benefits, habitat and kinship. Thematic collections in Bali Botanical Garden include collections of aquatic plants, cactus, orchids, ferns, Begonia, Bamboo, medicinal plants and religious ceremonial plants.

The entire collections of plants are recorded in the database of the registration unit in Bali Botanical Garden. Until March 2016 the number of the collections recorded by the registration unit is 21,502 plants consisting of 242 families, 1,078 genera, and 2,403 species. Besides collecting living plants, Bali Botanical Garden also collects 79 specimens of ethnobotanical artifacts. The collected artifacts are in the form of various kinds of household equipment, religious ceremony materials and farm equipment.

\section{Ethnobotanical Collections}

Ethnobotanical collections at Bali Botanical Garden are plant collections arranged in the form of gardens, and in the form of artifacts displayed in a display room. The display room is located in a traditional Balinese house that also serves as a guesthouse. The ethnobotanical plant collections are arranged in gardens based on their basic benefits. In Bali Botanical Garden, 


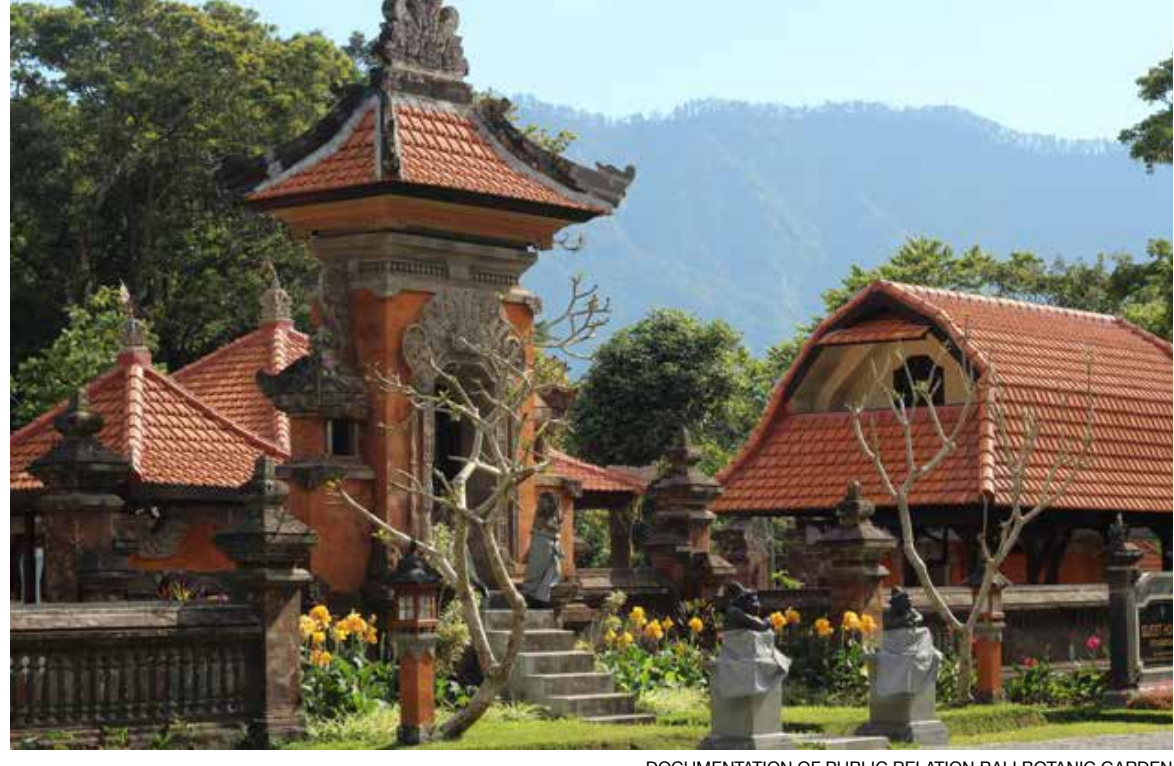

Figure 3. Traditional house "Ethnobotany Guest House"

of visitors during weekends, public holidays and school holidays. The peak season for domestic visits and student visits is in the period of May-June, during which school holidays usually take place. Meanwhile, the peak season for international tourist arrivals is in summer (August). Foreign tourists visiting Bali Botanical Garden are mainly from Australia, Japan, France, China and Germany.

\section{G. Characteristics of Visitors}

Based on the record from Information and Services Office of Bali Botanical Garden, the visitors consist of foreign tourists, domestic tourists and local tourists. Local tourists consist of groups/families and individuals. Bali Botanical Garden is also frequented by groups of local students and students coming from areas outside Bali.

\section{H. Visitors' Purposes}

The most common purpose of visitors coming to Bali Botanical Garden is to enjoy their vacation and some of the visitors come for research and educational activities. According to the data from Information and Services Office of Bali Botanical Garden, in 2015 there were 434,654 visits for tourist activities, 56,482 visits for student activities and 18,186 visits for other activities.

\section{Tour Packages}

Until 2016 Bali Botanical Garden does not have special tour packages such as ethnobotanical tour packages for tourists who visit the garden. Up until the present time, Bali Botanical Garden only provides environmental education programs for school group visitors. Considering the current con- 
Table 1. Data On The Number Of Visitors Coming To Bali Botanical Garden In 2015

\begin{tabular}{|c|c|c|c|c|c|}
\hline \multirow[b]{2}{*}{ Month } & \multicolumn{4}{|c|}{ Visitors } & \multirow[b]{2}{*}{ Total } \\
\hline & $\begin{array}{c}\text { Domestic } \\
\text { Tourists }\end{array}$ & $\begin{array}{l}\text { Foreign } \\
\text { Tourists }\end{array}$ & Students & Others & \\
\hline January & 45,514 & 4,210 & 259 & 1,814 & 51,797 \\
\hline February & 26,815 & 4,030 & 419 & 1,824 & 33,088 \\
\hline March & 27,442 & 3,150 & 1,620 & 2,832 & 35,044 \\
\hline April & 26,952 & 3,998 & 1,954 & 384 & 33,288 \\
\hline May & 40,311 & 3,777 & 12,546 & 1,960 & 58,594 \\
\hline June & 35,407 & 3,821 & 33,177 & 2,030 & 74,435 \\
\hline July & 65,210 & 6,391 & 2,638 & 382 & 74,621 \\
\hline August & 3,864 & 3,864 & - & 727 & 8,455 \\
\hline September & 26,245 & 2,995 & 227 & 502 & 29,969 \\
\hline October & 28,445 & 3,804 & 705 & 991 & 33,945 \\
\hline November & 25,940 & 2,017 & 240 & 1,521 & 29,718 \\
\hline \multirow[t]{2}{*}{ December } & 37,689 & 2,763 & 2,697 & 3,215 & 46,364 \\
\hline & \multicolumn{3}{|c|}{ Total } & & 509,318 \\
\hline
\end{tabular}

Source: Information and Services Office of Bali Botanical Garden

ditions in Bali Botanical Garden, in terms of the location, collection of plants and other facilities to support this tourism destination, it is very possible to design tour packages that can be offered to tourists.

\section{J. Human Resources}

Human resources have become an integral part of the development and management of ethnobotanical tourism. In Bali Botanical Garden, human resources in the field of botany with the support of data and literature on ethnobotany can make a positive contribution to developing the tourism potential. With good management of biological resources and human resources, it is very possible to realize the potential for the development of new tour packages.

\section{K. SWOT Analysis Matrix}

SWOT analysis in this paper serves to help analyze the potential for ethnobotanical tourism development in Bali Botanical Garden. Here are the results of the SWOT analysis presented in Table 2:

1. In line with the function of Bali Botanical Garden, ethnobotanical tourism in this area has the potential to be further developed.

2. The number of domestic and foreign tourist visits needs to be improved by developing the potential of ethnobotanical tourism.

3. Human resources professionals in the ethnobotanical tourism management need to be prepared.

4. The thematic gardens with the theme of ethnobotany need to be arranged.

5. Ethnobotanical information media and promotional activities need to 
be adequately provided.

6. Means of transports for ethnobotanical tourism activities need to be adequately provided.

7. More serious management of ethnobotanical tourism is required.

8. Any existing issues that hinder the development of ethnobotanical tourism potential with related parties should be settled.

9. Promotion and collaboration with relevant parties to develop ethno botanical tourism in Bali Botanical Garden need to be improved.

Table 2. SWOT Analysis Matrix

\begin{tabular}{|c|c|c|}
\hline & $\begin{array}{l}\text { Strengths (S) } \\
\text { 1. The current function of Bali } \\
\text { Botanical Garden } \\
\text { 2. The existing Institutional body } \\
\text { of Bali Botanical Garden } \\
\text { 3. The carrying capacity of the } \\
\text { land } \\
\text { 4. The environmental conditions, } \\
\text { and the collection of plants and } \\
\text { ethnobotanical artifacts in Bali } \\
\text { Botanical Garden }\end{array}$ & $\begin{array}{l}\text { Weaknesses (W) } \\
\text { 1. The management policies } \\
\text { 2. Tourism development planning } \\
\text { 3. Information and promotion } \\
\text { media } \\
\text { 4. The distance from one thematic } \\
\text { garden to another is consider- } \\
\text { ably far. } \\
\text { 5. The absence of ethnobotanical } \\
\text { tour packages }\end{array}$ \\
\hline $\begin{array}{l}\text { Opportunities (O) } \\
\text { 1. Tourist destinations around Bali } \\
\text { Botanical Garden } \\
\text { 2. Number of Visitors } \\
\text { 3. Access to the location } \\
\text { 4. Variety of visitors }\end{array}$ & $\begin{array}{l}\text { 1. Development of ethnobotanical } \\
\text { tourism potential is promis- } \\
\text { ing because it is in line with } \\
\text { the function of Bali Botanical } \\
\text { Garden } \\
\text { 2. Potential of tourist visits and } \\
\text { ethnobotanical tourism to } \\
\text { increase the number of visits to } \\
\text { Bali Botanical Garden }\end{array}$ & $\begin{array}{l}\text { 1. Information media and promo- } \\
\text { tions on ethnobotany need to be } \\
\text { adequately provided. } \\
\text { 2. Means of transport in the area } \\
\text { of Bali Botanical Garden need to } \\
\text { be adequately provided. } \\
\text { 3. There needs to be a more seri- } \\
\text { ous management of ethnobot- } \\
\text { anical tourism. }\end{array}$ \\
\hline $\begin{array}{l}\text { Threats (T) } \\
\text { 1. Commitment of the human } \\
\text { resources } \\
\text { 2. Status of land ownership }\end{array}$ & $\begin{array}{l}\text { 1. Human resources professionals } \\
\text { in the management of ethno- } \\
\text { botanical tourism needs to be } \\
\text { prepared. } \\
\text { 2. The arrangement of the eth- } \\
\text { nobotanical thematic gardens } \\
\text { needs to be made. }\end{array}$ & $\begin{array}{l}\text { 1. The role of policy makers to } \\
\text { alleviate the problems that } \\
\text { hinder the development of } \\
\text { ethnobotanical tourism needs to } \\
\text { be optimized. } \\
\text { 2. Promotion and collaboration } \\
\text { with relevant parties to develop } \\
\text { ethnobotanical tourism need to } \\
\text { be improved. }\end{array}$ \\
\hline
\end{tabular}

\section{Conclusion}

Bali Botanical Garden located in the Bedugul tourist area is one the main tourist destinations in Bali. It has a collection of 21,502 plants divided into general and thematic collections. There are two thematic collections related to ethnobotany, namely the collection of medicinal plants (Usada Medicinal Garden) and a collection of religious ceremonial plants (Panca Yadnya Garden). In addition to collecting living plants, this botanical garden also collects ethnobotanical artifacts displayed in a display room in a traditional Balinese house located on the site. In line with its function as a plant conservation body which is also a tourist destination area, the potential of the collections related to ethnobotany needs to be further developed. Certainly, commitment of the management to develop the ethnobotanical tourism in the area is required. Provision of supporting facilities, cooperation with relevant parties such as 
tourism businesses, local governments, and the public is absolutely needed. Promotional activities must be intensified in order that the ethnobotanical tourism potential can be developed well and has positive benefits for science, the tourism industry and the welfare of the communities.

\section{Acknowledgment}

We would like to thank Sutomo, S.Hut, M.Sc. (PhD Candidate) and Wawan Sujarwo, PhD for his constructive comments and various supports.

\section{References}

Damanik, Janianto and Helmut F. Weber. 2006. Perancangan Ekowisata. Yogyakarta :

Penerbit Andi.

Jain, S. Mudgal. 1999. A Hand Book Of Ethnobotany. India : New Conclught Place. Laporan Tahunan Kebun Raya Bali 2015.

Muntadliroh.2016.Strategi Komunikasi Pemasaran Terpadu Ekowisata Dikebun Raya Eka

Karya, Bedugul Bali. JUMPA 3[1]: 40 - 59.

Ramadhanil Pitopang dan Panji Anom Ramawangsa. 2016. Potensi Penelitian Etnobotani di

Sulawesi Tengah Indonesia.Online Journal of natural Science Vol 5(2) : 111-131

Suryadarma, IGP. 2008. Diktat Kuliah Etnobotani. Yogyakarta : Jurusan Pendidikan Biologi

FMIPA,Universitas Negeri Yogyakarta.

Pendit, I Nyoman S. 1994. Ilmu Pariwisata Sebuah Pengantar Perdana. Jakarta : Prandya Paramita.

\section{Profil Penulis}

I Gede Wawan Setiadi S.Sn, was born in Singaraja 24 Januari 1980. in 2003 graduated bachelor degree from Universitas Pasundan Bandung, Faculty of Art and Design with focus on visual communication design. in 2003 started his career as staff documentation and information at Bali Botanic Garden. Email: Email: i.gede.wawan. setiadi@lipi.go.id

Renata Lusilaora Siringoringo, was born in Cimahi 13 Juli 1985. In 2006 graduated diploma degree from Sekolah Tinggi Pariwisata Bandung. Currently being continued at University Dwijendra Denpasar in the faculty of communication sciences . In 2006 began her career in the hospitality industry, as a receptionist, reservation staff, and the latest as front office supervisor. In 2009 until now as public relation at Bali Botanic Garden. Email: nata_lusilaora@yahoo.com 